\title{
An Invasion into the Utopic World of Alison and Laura: Exploring Osborne and Williams' Perspective
}

\author{
Sayantani Sengupta
}

\begin{abstract}
M.A. English, Amity Institute of English Studies and Research, Amity University, Kolkata, India Email- sayantanisengupta00@gmail.com
\end{abstract}

\begin{abstract}
Being dissatisfied with their own existence and utterly depressed with the imperfect scenario, individuals portray the tendency to travel beyond the attainable space and undertake an imaginary, impractical, creative and constructed journey to the ideal space, which they regard as their epitome of perfection or an alternate society and term it as utopic world. Even though the characters enjoy a momentary existence, they suffer from the dilemma of encountering the subversion of dreams and invasion of an outside element capable enough behind their devastation and crumbling down of the dreams. Such a definitive perspective can be witnessed through the reclusive Laura in Tennessee Williams' The Glass Menagerie as she feels herself different from the others and finds escape and solace in her collection of glass animals. Similar viewpoint can be projected through Alison in Look Back in Anger who keeps herself engaged with the household chores being dissatisfied with her marital relationship. Thus, exploring and objectifying the utopic world of Laura and Alison in the ground-breaking texts of Williams and Osborne. Divided into several parts, the paper focuses on the lives of Laura and Alison and highlights the concept of an 'outsider' through the characters of Jim and Helena respectively. The tendency of Tom Wingfield and Jimmy Porter to relive their past also holds an important section here. Both the plays are analysed critically along with reference to other characters that has influenced the main plot.
\end{abstract}

Keywords-utopia, identity crisis, existential problems, outsider element, past life, fragility.

\section{UNDERS TANDING THE TERM 'UTOPIA'}

Utopianism is well-knit with the nature of man and its existence can be traced even before Sir Thomas More coined the term in 1516 and showcased it as a place of habitation. According to Oscar Wilde, "A map of the world that does not include utopia, is not worth glancing at, for it leaves out the one country at which humanity is always landing." The term 'utopia' has been defined from various angles by different scholars and critics however, the root of the word, from where it has been coined contains two Greek words, "ou-topos" meaning "no place" and "eu-topos" meaning "good place". Almost all the utopian writings reflect this duality of meaning and that makes the work more critical and interesting. Being on the one hand "fantasies of a desirable but unattainable perfection" and on the other "visions of good and possibly attainable social systems". Another conception of utopia is that of a distant land which is perfect, allegedly found and described by a traveller, who eventually returns to narrate about his experience in such a wondrous place. Reference to this type can be detected in Homer's Odyssey, in the impressions of the Spanish explorer Garcilaso de la Vega of the Inca empire (1617), in Johann Andreae's Christianopolis 1619, in the Dominican Tommaso Campanella's City of the Sun(1623), in Francis Bacon's New Atlantis(1627). However, while creating this new and celebrated term 'utopia', More's intension was to hint at an alternative society. In this way, the term has evolved with the course of time and the major concept has been included by several writers in their works.

This paper focuses on the 'utopic' world of Alison from Osborne's Look Back in Anger and Laura from Williams' The Glass Menagerie and the multiple layers of reasons behind their approach towards creating a different world for themselves. When they both try to feel comfortable in their own worlds, 'outsiders' intrude and shatter their alternative world. The two major male characters of the plays, Jimmy Porter and Tom Wingfield have also been critically analysed who play a significant role in both Alison and Laura's lives respectively. Their tendency of reliving the past glories and their present dissatisfaction have been projected in this paper along with the utopic worlds of the two female characters.

\section{AN INSIGHT INTO LOOK BACK IN ANGER AND THE GLASS MENAGERIE}

In 1950s and 1960s, a new type of drama was introduced which was quite different from the previous 
forms and it was named as the 'Theatre of the Absurd' and 'Kitchen-sink drama'. These forms primarily projected the life of a man trapped in the hostile universe, where he or she does not want to live and where there is no sign of happiness, prosperity and hope for future. Martin Esslin wrote on the people who belonged to the theatre of the Absurd, in his The Theatre of the Absurd, "is an individual who regards himself as a lone outsider, cut off and isolated in his private world .... with his own personal approach both to subject matter and to form, with his own roots, sources and background". Look Back in Angeris considered to be one of the dramas from The Theatre of the Absurd and it can also be categorised as a Kitchen-sink drama due to its style and content. As the characters in the play feel trapped in their present situation, they try to figure out their own ways to find momentary solace. Alison, wife of Jimmy Porter belongs to an upper-class family, but she married an individual who is lower in status and class. This class difference often creates a conflict between the couple and Jimmy projects his anger in front of his wife and friend, Cliff Lewis. The reason behind his anger is not one but multiple which has led to his unhappiness in marital life as well. Alison finds escape through her household chores and wants to create a separate world for herself where she will be the only part. However, this is only possible for some time since there is no ideal or perfect place to live in. Not only her household tasks but also the bear and squirrel game give the couple some form escape from the futile, hostile and frustrated surroundings. Whenever they have a conflict, Jimmy and Alison prefer to play the bear and squirrel game, where Jimmy pretends to be a bear and Alison, a squirrel and express their affection towards each other. Towards the middle of the play, Helena, Alison's friend's arrival is at Jimmy's house is mentioned by Osborne. This event changes the angle from which the play has been approached and marks certain alterations in the characters as well. Helena's feelings towards Jimmy and vice versa is not distinctly pointed out but an element of an 'outsider' can already be felt by the readers. Helena intruded into the complicated lives of Jimmy and Alison and shared a close bonding with Jimmy which was not expected. However, Helena's conscience did not let her stay over there for a long period of time and she soon left the house. After Helena's departure from Jimmy's attic room after Alison's arrival from her father's house, the couple tries to understand each other's condition and plays this bear and squirrel game but this time several questions may arise in the readers mind. Will the two of them actually find an escape from the trapped situation and be able to live on their own? Will the game have a similar impact on them after Jimmy's closeness with Helena in his wife's absence? Is Alison really successful in creating a utopic world for herself? Even though Alison did not express much but she could feel her own world getting shattered by the presence of an 'outsider'. The bear and squirrel game is probably no longer her escape and she returns to her presence in the unfulfilling and unsatisfactory outside world.

Written at the backdrop of the Great Depression in the USA, Tennessee Williams' The Glass Menagerie highlights the fate of women characters and their victimization in the shattered and futile world. Laura Wingfield, one of the major female characters of the play, feels herself to be different from the others and is projected as a fragile young lady. Laura's mental fragility handicaps her more than her physical defect. The contrast between Laura's withdrawal and Amanda's desperate struggle to get her out of her own created world and change her into an independent girl can be repeatedly witnessed throughout the play. However, Laura is satisfied to portray herself as a dependent girl and is happy in her fragile world of glass animals. Laura refuses to cross the threshold to embrace the new life. She drops out of school and wastes her life in wandering in the park and going to the movies. When she needs to move ahead so that she can be free and independent, she chooses to retreat, because she is "not used to confronting fear and going beyond it." Internally, she is isolated and alienated by her physical defect, lack of confidence, and withdrawal from society. She denies her mother's domination, rejects her illusionary expectations, and refuses to return to the "old south". But at the same time, she alienates herself from society and fails to step out of her confinement. Unable to adjust herself with the outside world, Laura has created her glass menagerie, where she finds solace in her collection of glass animals. The glass menagerie is a symbol of her physical and emotional fragility. Delma E. Presley opines that Laura's existence "revolves around her collection of transparent glass animals and the menagerie is her means of escaping from family tensions and her own sense of futility." The primary essentials of her life are acceptance of her condition, her isolation and escape from reality which is too hard for her to fathom. Maybe, she will be an outsider in the outer world where people reside but in her glass world, she is an important part and no longer an outsider.

\section{HELENA AND JIM AS AN 'OUTSIDER'}

Look Back in Anger by Osborne commences with the introduction of the main characters, Jimmy, Alison and Cliff in their small attic room. Jimmy's frustrated, angry nature has been highlighted from the first act of the play along with their simple lifestyle in a post-war scenario. He shuns his responsibilities towards his wife Alison and their friend Cliff is the one to take 
care of her. The situation accentuates with the arrival of Alison's friend Helena, who is an actress, in their small family. Through the bear and squirrel game and her household tasks, Alison had found her alternate or utopic world where she could take a retreat from reality and somewhat adjust herself with her situation. However, Helena's arrival and interference in their personal life shatters Alison's private world and brings her in front of the harsh reality where she is a mere victim of the male dominance. Soon, she calls Alison's father to take her away and when she is gone, Helena moves in with Jimmy. Alison returns to Jimmy's house after some time and Helena leaves as soon her friend arrives. In Alison's absence she also becomes very close to Jimmy, physically as well as emotionally but soon she is able to recognise Jimmy's true angry nature. Helena finds it difficult to adjust with such an individual because unlike Alison, she is not ready to sacrifice her blissful life and stay with Jimmy. She is described as having a "sense of matriarchal authority" that "makes most men who meet her anxious."It is figured out how an outsider can arrive and forcibly enter the personal world of a family and try to destroy it. Though Helena's intentions are not clear enough, but the readers can predict and trace her intentions from her behaviour towards Jimmy and Alison. However, she is unable to separate the couple and her conscience, and her middle-class morality make her leave the house after Alison's arrival from her father's house.

Laura's small world of her own, in Williams' The Glass Menagerie is disturbed and shattered when Jim, a gentleman caller intrudes into her life. This intrusion happens much later in the play which gives the dramatist enough time and space to develop the conflicts between Laura and her dominating mother, Amanda so that the dramatic tension of intrusion is enormously widened. The preparation for the arrival of Jim and the expectations of forming a romantic relationship with him are thoroughly described to prepare the audience for a tragic outcome. What is more closely related to the romantic conventions is that Amanda urges Laura to make a wish of "happiness" and "goof fortune" by the "little silver slipper of a moon," which reminds Laura and the audience of Cinderella's happy ending. However, the true motives of Williams will be soon revealed and all the expectations of the characters as well as the audience will be shattered. This unique situation before the arrival of the gentleman caller has been described by Arthur Miller as "an eloquence and amplitude of feeling". The difference between the expectation of an impending marriage of Laura and the harsh reality is described minutely by the playwright. The setting also looks different since Amanda has tried to transform the living room into a place filled with warmth of love and romance. Even Tom's description of Jim suggests that a romantic event will soon take place but in reality, the opposite happens. Williams presents Jim as a simple and average man, who, according to Tom, is too realistic. When Jim finally arrives, he is recognised by Laura since this is the boy whom she secretly loved and admired from her high school days. However, he does not come into her life to give her a relief from her difficult life and rescue her to some other place. He only intrudes to make her life more miserable and shatter all her dreams. He accidentally breaks the horn of the special glass unicorn in the collection and turns it into an ordinary horse. The unicorn loses its uniqueness and so does Laura. She loses all her confidence and self-power because maybe deep inside she could not accept the interference of Jim and the ultimate destruction.

Hence, the powerful and destructive impact of an 'outsider' can be felt in both the plays. Helena and Jim arrive in the respective worlds of Alison and Laura to make them feel like an outsider in their own space, since the fine line of distinction between the outer world and the inner utopic world of the characters are fragmented. They step into their personal lives and make it so different that returning to the original space is not possible for them anymore.

\section{ANALYSING THE TENDENCIES OF JIMMY AND TOM TO RELIVE THE PAST}

Jimmy Porter in Look Back in Anger has been portrayed as an angry young man of the post-war generation and the reason behind his nature is multiple. After the World War everything was destroyed and the people were facing severe economic and social problems which affected their state of mind and well-being. Many things were promised to the people, but it was broken after the war ended and the misery of people continued. Jimmy is the representative of the age and tries to relive the glorious past which is long lost. He feels that nothing can offer him new and substantial things, hence in Act I, he says, "Why do I do this every Sunday? Even the book reviews seem to be the same as last week's. Different books - same reviews."Jimmy realized that the much celebrated and conceited 'Welfare State' ended up in nothingness and the 'Brave New World' that was so fondly envisioned was being thwarted. The Imperial glory of England waned, and the position of England was grossly reduced to insignificance in the international scenario. The Anglo-French armies faced major reverses in the issue of possession of Suez. Russia succeeded in suppressing the Civil Revolt in Hungary while the rest of the World, particularly England, stood and watched. Lastly, America's rapid, undebatable and unchallenged ascendancy made things worse. He is also against class 
distinction and condemns his wife and her aristocratic family. He holds them responsible for his present condition and the bleak condition of the state at large. Jimmy tries to find some meaning and solace from the glorious past.

On the other hand,when Tom returns to his past, he feels the guilt about abandoning his family for another life. The play is composed from the perspectives of Tom's memories. He feels trapped in the monotonous job life and the problems of his family. He visits the movie theatres at night and finds pleasure in alcohol and cigarettes. Tom's movement between his desire for freedom and his inability to escape develops an underlying tension throughout the play and when he relives those moments while narrating the play, he feels the guilt due to his irresponsible deeds. Amanda's husband had abandoned their family and Tom was left with the duty to look after them as the only remaining male member. However, he never showed his responsibility towards his mother and his crippled sister, Laura. He was busy with his own life, trying to fill the gap by doing various tasks. Hence, his guilt-conscious mind is well-highlighted in the play.

\section{CONCLUSION}

Williams and Osborne have successfully projected the Utopic world of Alison and Laura with the assistance of the setting, historical and political background as well as through the presence of other important characters. Even in their imperfect world, Laura and Alison have tried to put aside all the hurdles and create their own unique space. However, they have failed to do so for a long period of time since their space have been interfered by other members and have made their lives more difficult. Both the female characters have not given up on their lives and situations and they are struggling each and every moment to find a hope where they can cling on.

This paper has tried to answer some of the prominent questions like,can anyone actually create an ideal and alternate world to live in? Are Laura's glass collection and Alison's bear and squirrel game an escape from reality? Can the outer world be avoided completely? Lastly, is Utopia a possibility or just a myth?

Perhaps, escaping the reality completely is not possible since we all are a part of the society and the surrounding. An alternate world can be created for a considerable period of time, but it gets demolished soon and again they are exposed to the harsh reality.

\section{REFERENCES}

[1] Esslin. Martin, The Theatre of the Absurd. Bloomsbury Publishing India Private Limited, 2001 Print

[2] Faber. M.D., 'The Character ofJimmy Porter: An Approach to Look Back in Anger', Modern Drama, 13, 1, May, 1970.

[3] Miller.Arthur, Collected Essays. Penguin Classics. 2016 Print

[4] Millet.Kate, Sexual politics, (New York: Doubleday and Company 1970)

[5] Osborne. John, Look Back in Anger. Pearson Education, 2011 Print

[6] Williams. Tennessee. The Glass Menagerie. Bloomsbury Publishing India Private Limited, 2014 Print

[7] Williams. Tennessee. The Glass Menagerie. Salisbury Playhouse.

[8] https://owlcation.com/humanities/Laura-WingfieldThe-Blue-Rose-and-Unicorn

[9] https://www.litcharts.com/lit/look-back-inanger/characters/jimmy-porter

[10] http://shodhganga.inflibnet.ac.in/bitstream/10603/57 849/7/07 chapter\%201.pdf 